\title{
GMR
}

\section{A rare case of trisomy 11q23.3-11q25 and trisomy 22q11.1-22q11.21}

\author{
P.-S. Zou ${ }^{1 *}$, H.-F. Li ${ }^{2 *}$, L.-S. Chen ${ }^{1}$, M. Ma ${ }^{1}$, X.-H. Chen ${ }^{1}$, D. Xue ${ }^{3}$ and \\ D.-H. $\mathrm{Cao}^{1}$
}

${ }^{1}$ Aristogenesis Center, No. 202 Hospital of PLA, Shenyang, China

${ }^{2}$ Genetic Laboratory, Women and Children's Hospital of LinYi City, LinYi, China

${ }^{3}$ Special Clinical Department, No. 202 Hospital of PLA, Shenyang, China

*These authors contributed equally to this study.

Corresponding author: D.-H. Cao

E-mail: dhcao427@sina.com

Genet. Mol. Res. 15 (2): gmr.15028140

Received November 25, 2015

Accepted January 6, 2016

Published May 6, 2016

DOI http://dx.doi.org/10.4238/gmr.15028140

\begin{abstract}
Partial duplication of the long arm of chromosome 11 and the partial trisomy of $22 q$ are uncommon karyotypic abnormalities. Here, we report the case of a 6 -year-old girl who showed partial trisomy of $11 \mathrm{q}$ and $22 \mathrm{q}$, as a result of a maternal balanced reciprocal translocation $(11 ; 22)$, and exhibited dysmorphic features, severe intellectual disability, brain malformations, and speech delay related to this unique chromosomal abnormality. Array comparative genomic hybridization (array CGH) revealed a gain in copy number on the long arm of chromosome 11, spanning at least $18.22 \mathrm{Mb}$. Additionally, there was a gain in copy number on the long arm of chromosome 22, spanning at least $3.46 \mathrm{Mb}$. FISH analysis using a chromosome 11 short arm telomere probe (11p14.2), a chromosome 11 long arm telomere probe (11q24.3), and a chromosome 22 long arm telomere probe (22q13.33) confirmed the origin of the marker chromosome. It has been confirmed by the State Key Laboratory of Medical Genetics of China that this is the first reported instance of the karyotype 47,XX, $+\operatorname{der}(22)$
\end{abstract}


$\mathrm{t}(11 ; 22)(\mathrm{q} 23.3 ; \mathrm{q} 11.1)$ mat in the world. Our study reports an additional case that can be used to further characterize and delineate the clinical ramifications of partial trisomy of $11 \mathrm{q}$ and $22 \mathrm{q}$.

Key words: Karyotype; DiGeorge syndrome; Velocariofacial syndrome; Array CGH; FISH; Balanced reciprocal translocation

\section{INTRODUCTION}

A balanced reciprocal translocation is an exchange in which chromosomal segments from two non-homologous chromosomes break off, translocate, and fuse at the breakpoint on the reciprocal chromosome. Carriers of balanced reciprocal translocations have an increased risk of generating chromosomally unbalanced offspring, due to partial microduplication or microdeletion of chromosomal segments. Partial microduplication of the long arm of chromosome 11 is relatively rare, and was first reported in a patient in 1977 (Francke et al., 1977). Recently, partial microduplication of chromosome 11q has been recognized as a rare disorder. The majority of trisomy 11q events are a result of abnormal meiotic segregation of a parental reciprocal translocation involving chromosome 11 and another chromosome (Yelavarthi and Zunich, 2004). Additionally, the 22q11.2 microduplication syndrome has been recently identified. Patients who present this novel chromosomal disorder display symptoms that overlap substantially with those of DiGeorge/Velocardiofacial syndrome (Wentzel et al., 2008).

Here, we report the case of a 6-year-old girl with partial trisomy of $11 \mathrm{q} 23.3 \circledR 11 \mathrm{q} 25$ and $22 \mathrm{q} 11.1{ }^{\circledR} 22 \mathrm{q} 11.21$. The partial trisomy of $11 \mathrm{q}$ and $22 \mathrm{q}$ is the result of an unbalanced translocation between 11q23.3 and 22q11.1 from the parental chromosomes. The resultant phenotypic features overlap with features of $11 \mathrm{q}$ terminal duplication syndrome, including dysmorphic facial features, microcephaly, micrognathia, dysplastic ears, pre/postnatal growth retardation, speech delay, mental retardation, hypotonia, neural tube defects, as well as cardiac, vertebral, limb, urinary tract, and genital anomalies. Patients with 22q11.2 microduplication syndrome have variable clinical features including intellectual disability, telecanthus, downslanting palpebral fissures, long narrow face, nasal speech, speech impairment, delayed psychomotor development, growth retardation, hypotonia, and velopharyngeal insufficiency. The main factors contributing to these clinical features are the length of the trisomic region and the genomic content of the break point.

\section{MATERIAL AND METHODS}

\section{Clinical report}

Patients and/or guardians consented to their information being used in this study and for future research. Patient information was not anonymized. All authors have access to the relevant identifying information, and the verbal consent is documented in patient files. The mother of the patient consulted our aristogenesis center for karyotype analysis of the patient presenting severe clinical features including growth retardation, speech delay, and mental retardation. The non-consanguineous couple had been married for 3 years, and the patient was their first child. During the pregnancy, symptoms of spontaneous abortion were detected, 
and progesterone was administered to prevent miscarriage. A fetal sonography and prenatal screening showed no obvious abnormality. In the 39th week of gestation, the patient was uneventfully born by eutocia and weighed $3400 \mathrm{~g}$. At the age of 3 years, the patient could sit without support, but could not yet walk, and her speech was limited to one word. At the age of 6 years, the patient could stand, but displayed a festinating gait, and no progress in speech development. On physical examination, the patient showed developmental delay, speech impairment, mental retardation, hypotonia, microcephaly, micrognathia, a long narrow face, a high arched palate, a short nose, and nasal speech. Magnetic resonance imaging showed agenesis of the corpus callosum, cerebellar vermis hypoplasia, and simple cerebral gyration. The patient received encephalopathy rehabilitation treatment, but this was ineffective.

\section{Cytogenetic analysis}

Short-term phytohemagglutinin-stimulated peripheral blood lymphocyte cultures were obtained from the blood of the patient and her parents. Chromosomal analysis was carried out by applying G-banding at a 500-band level, according to ISCN 2013. At least 30 metaphase plates were analyzed for each individual. Karyotyping was performed using an image analyzer (Leica CW4000, Leica Microsystems Imaging Solutions Ltd., Cambridge, England).

\section{Array comparative genomic hybridization (CGH) analysis}

Genomic DNA was isolated from the patient's peripheral blood. Array CGH was performed using oligonucleotide-based custom arrays (Agilent Technologies, Santa Clara, CA, USA) using a standard protocol. Briefly, equal amounts of test DNA and normal sexmatched DNA were digested with $A l u \mathrm{I}$ and $R s a \mathrm{I}$, and differentially labeled with cyanine-5 (cy5) and cyanine-3 (cy3) fluorescent dyes using a SureTag Complete DNA Labeling Kit (Agilent Technologies). Hybridizations were carried out at $65^{\circ} \mathrm{C}$ for $24 \mathrm{~h}$. After washing, slides were scanned using an Agilent SureScan Microarray Scanner (Agilent Technologies) and the images were extracted and analyzed using Feature Extraction v11.5 (Agilent Technologies) and Cytogenomics v2.5 (Agilent Technologies) softwares, respectively. Web resources included the Database of Genomic Variants: (http://dgv.tcag.ca/dgv/app/home), OMIM: (http://omim.org/), DECIPHER: (http://decipher.sanger.ac.uk/), and: (http://www.ncbi.nlm. nih.gov/pubmed).

\section{Fluorescence in situ hybridization (FISH) analysis}

Following the results of cytogenetic analyses and array CGH, FISH analysis was performed using the following probes: TelVysion 11 short arm telomere Spectrum Orange indicating RP11-16H3 (11p14.2, $170 \mathrm{~kb})$, TelVysion 11 long arm telomere Spectrum Red indicating RP11-608N11 (11q24.3, $170 \mathrm{~kb}$ ), and TelVysion 22 long arm telomere Spectrum Green indicating RP11-164E23 (22q13.33, $154 \mathrm{~kb})$, according to the manufacturer instructions. FISH was performed on blood lymphocytes blocked at metaphase according to a standard protocol. The hybridized chromosomal spreads were analyzed using a fluorescent microscope equipped with appropriate filters and CytoVision. Slides were scored by the number of probe signals at each metaphase. For each target area, ten hybridized metaphase cells were analyzed. 


\section{RESULTS}

Conventional cytogenetic analysis showed the patient's karyotype was $47, \mathrm{XX},+$ mar. Further, we analyzed the karyotypes of the patient's parents and found that the mother's karyotype was a balanced de novo translocation between the long arm of chromosome 11 and the long arm of chromosome 22 ; the maternal karyotype was $46, \mathrm{XX}, \mathrm{t}(11 ; 22)(\mathrm{q} 23.3 ; \mathrm{q} 11.1)$ (Figure 1A and B). The father had a normal karyotype. As a result of the maternal origin of this defect, the patient's karyotype was designated as 47,XX, $+\operatorname{der}(22) \mathrm{t}(11 ; 22)(\mathrm{q} 23.3 ; \mathrm{q} 11.1)$ mat (Figure 1B); the patient was trisomic for segment 11q23.3®11q25 and 22q11.1®22q11.21.

A

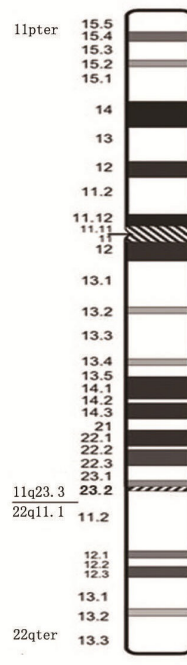

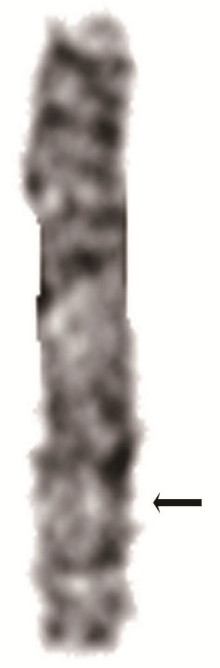

B

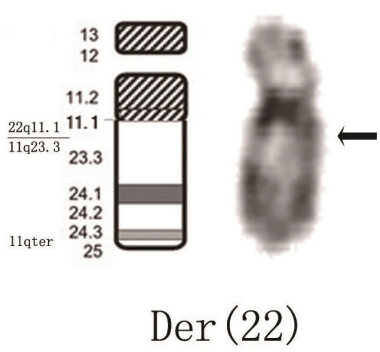

$\operatorname{Der}(11)$

Figure 1. G-banding partial karyotype of the proband and ideogram corresponding to 450-550 band levels as described by ISCN. The arrows indicate the breakpoints; Partial karyotype of patient's mother shows reciprocal translocation of $\mathrm{t}(11 ; 22)$. A. Der(11)(11pter $\left.{ }^{\circledR} 11 \mathrm{q} 23.3:: 22 \mathrm{q} 11.1{ }^{\circledR} 22 \mathrm{qter}\right)$. B. Der(22)(22pter ${ }^{\circledR} 2 \mathrm{q} 11.1:: 11 \mathrm{q} 23.3{ }^{\circledR} 1$ 1qter). The patient inherited the derivative chromosome der(22) from her mother.

Array CGH analysis of the patient's DNA revealed a gain in copy number on the long arm of chromosome 11, spanning at least $18.22 \mathrm{Mb}$, and a gain in copy number on the long arm of chromosome 22, spanning at least $3.46 \mathrm{Mb}$. The chromosomal breakpoints were precisely localized by array CGH on 11q23.3q25 (116740001-134960000) x 3 and 22q1 1.1q11.21(16840001-20300000) × 3 (Table 1). The presence of the additional derivative chromosome 22 resulted in the trisomy of the 22q11.1-22q11.21 and 11q23.3-11q25 segments in this individual.

FISH performed on metaphasic lymphocytes of peripheral venous blood using probes of chromosomes $11 \mathrm{p}, 11 \mathrm{q}$, and $22 \mathrm{q}$, revealed the maternal balanced translocation between chromosomes 11 and 22 (Figure 2A). The patient's karyotype indicated that the marker chromosome is an additional derivative of chromosome 22 [der(22)], resulting from an unbalanced translocation between the long arms of chromosomes 11 and 22 (Figure 2B). 


Table 1. Array CGH analysis results.
\begin{tabular}{l|c|c|c|c}
\hline Change & Chromosome & Interval & Size $(\mathrm{Mb})$ & Number of genes affected \\
\hline GAIN & $11 \mathrm{q} 23.3 \mathrm{q} 25$ & $116740001-134960000$ & 18.22 & $>20$ \\
\hline GAIN & $22 \mathrm{q} 11.1 \mathrm{q} 11.21$ & $16840001-20300000$ & 3.46 & $>20$ \\
\hline
\end{tabular}

Nucleotide positions based on hg19. Arr 11q23.3q25 (116740001-134960000) x 3. Arr 22q11.1q11.21 (14467972$30719733) \times 3$.
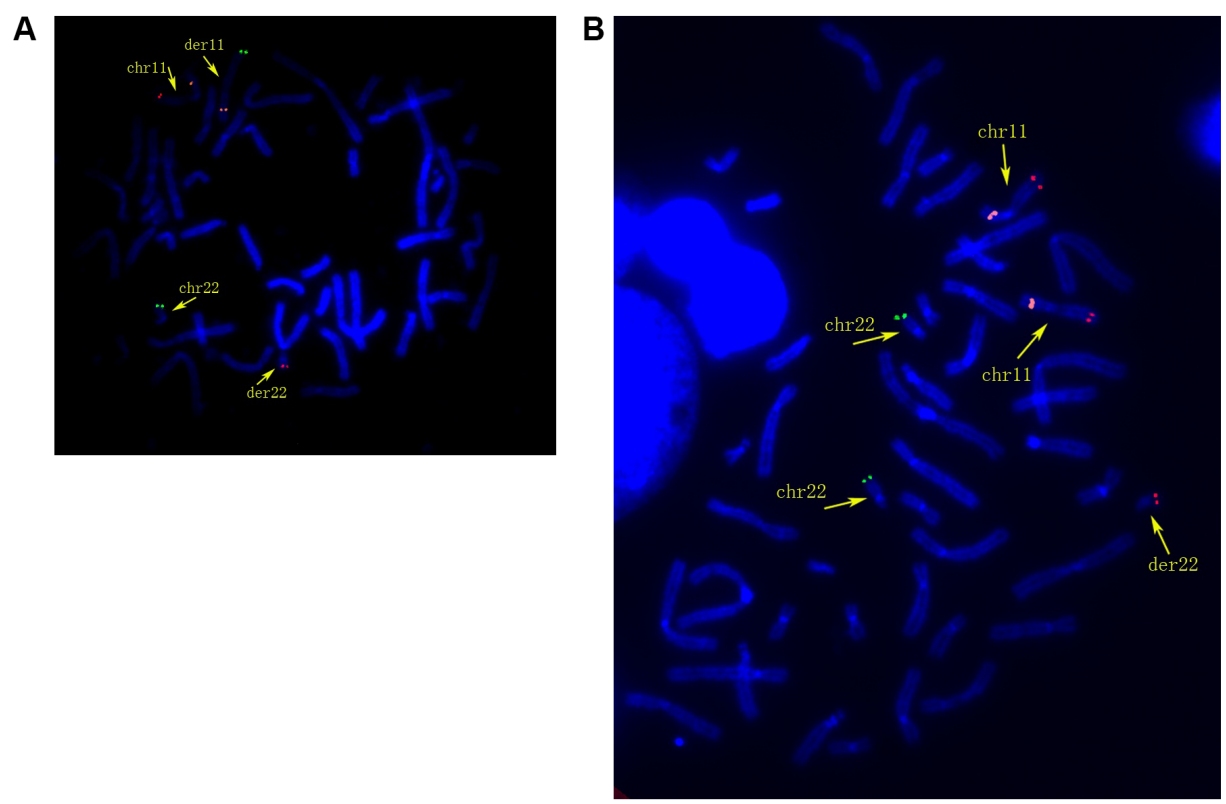

Figure 2. FISH analysis of cells arrested at metaphase. A. The patient's mother karyotype. B. The patient's karyotype. Orange marks indicate RP11-16H3 (11p14.2, $170 \mathrm{~kb})$; red marks indicate RP11-608N11 (11q24.3, 170 $\mathrm{kb})$; green marks indicate RP11-164E23 (22q13.33, $154 \mathrm{~kb})$. FISH results using three chromosome painting probes specific for chromosomes 11 and 22 show the derivative chromosome, der(22).

\section{DISCUSSION}

Unbalanced chromosomal abnormalities are uncommon structural aberrations that occur frequently due to unbalanced meiotic segregation in the gametes of balanced translocation carriers (Pfeiffer and Schütz, 1993; Yelavarthi and Zunich, 2004; Tuğ et al., 2014). Here, we described a maternal proband who carried a balanced reciprocal translocation between chromosomes 11 and 22, and who gave birth to an unbalanced progeny. Array CGH analysis revealed a microduplication at 11q23.3-11q25 and 22q11.1-22q11.21 genomic regions, covering 18.22 and $3.46 \mathrm{Mb}$, respectively. Therefore, the patient had both partial trisomy $11 \mathrm{q}$ syndrome and partial trisomy $22 \mathrm{q}$ syndrome.

Partial duplication of the long arm of chromosome 11 is relatively rare, and was first reported in 1977 (Francke et al., 1977). Later, trisomic segments of a partial trisomy 11q syndrome were reported: 11q13-11qter, 11q14-11qter, 11q21-11qter, 11q22-11qter, and 11q23-11qter (Greig et al., 1985). The most frequent breakpoint on chromosome 11 described by these studies was the same as in our case, at $11 \mathrm{q} 23$. However, it should be noted that 
breakpoints might lead to interruptions of specific gene loci, and may vary between patients, resulting in different disease phenotypes (Zimberg-Bossira et al., 2011). We compared a series of partial duplications of 11q23 described in eight cases, as previously published (Table 2). This was done to identify common genetic features that can explain the occurrence of severe congenital malformations including intellectual disability, growth retardation, dysmorphic features, abnormal muscle tone, brain abnormalities, neural tube defects, and cardiac and urinary tract abnormalities in patients with the partial trisomy 11q23 syndrome (Forsythe et al., 1988; Pfeiffer and Schütz, 1993; Smeets et al., 1997; Delobel et al., 1998; Klaassens et al., 2006; Partida-Pérez et al., 2006; Burnside et al., 2009; Zimberg-Bossira et al., 2011). The highly variable clinical features of trisomy 11q23 syndrome can be attributed to the different sizes of the duplicated region (Yelavarthi and Zunich, 2004; Klaassens et al., 2006). The abnormal clinical features presented by our patient likely resulted from the large distal gain in 11q23.3-q25 of the supernumerary derivative of chromosome 22, which contains several genes. Intellectual disability, developmental delay, and speech delay have been described in nearly all patients with partial trisomy of 11q, and were also observed in our patient.

Table 2. Comparison of phenotypic features of patients with overlapping regions of partial duplication of 11q.

\begin{tabular}{|c|c|c|c|c|c|c|c|c|c|}
\hline Clinical features & Forsythe et al. (1988) & $\begin{array}{c}\text { Pfeifffer and } \\
\text { Schütz (1993) }\end{array}$ & $\begin{array}{l}\text { Smeets et al. } \\
\text { (1997) }\end{array}$ & $\begin{array}{l}\text { Delobel et al. } \\
\text { (1998) }\end{array}$ & $\begin{array}{l}\text { Klaassens et al. } \\
(2006)\end{array}$ & $\begin{array}{l}\text { Partida-Pérez et al. } \\
(2006)\end{array}$ & $\begin{array}{l}\text { Burnside et al. } \\
(2009)\end{array}$ & $\begin{array}{l}\text { Zimberg-Bossira et al. } \\
(2011)\end{array}$ & Present study \\
\hline $\begin{array}{l}\text { Case reference and } \\
\text { karyotypes }\end{array}$ & $\begin{array}{c}46, \mathrm{XX}, \mathrm{dup}(11)(\mathrm{q} 23.3 \mathrm{q} \\
24.2)\end{array}$ & $\begin{array}{l}46, \mathrm{X} Y \text {,dup(11) } \\
\text { (q23qter) }\end{array}$ & $\begin{array}{l}\text { Patitent } 246, \mathrm{XY}, \\
\text { der(13)t(11;13) } \\
\text { (q23)p13)mat }\end{array}$ & $\underset{(\mathrm{q} 23.3)}{46, \mathrm{XX}, \mathrm{dup}(11)}$ & $\begin{array}{c}\text { Patient } 146, \mathrm{XY}, \\
\text { der(12)t(11;112) } \\
(\mathrm{q} 23 ; \mathrm{q} 24) \text { mat }\end{array}$ & $\begin{array}{c}46, X Y, \text { dupp(11)(q23q } \\
23)\end{array}$ & $\begin{array}{l}\text { Patitent } 1 \text { 1 } 46, \mathrm{XY}, \\
\text { ins(11)(q13.1 } \\
\text { q23.3q24.2)pat }\end{array}$ & $\begin{array}{c}46, \mathrm{XY}, \mathrm{der}(21) \mathrm{t})(11 ; 21)( \\
\mathrm{q} 23.1 ; \mathrm{q} 22.2) \text { pat }\end{array}$ & $\begin{array}{c}47, \mathrm{XX}, \\
+\operatorname{der}(22) \mathrm{t}(11 ; 22)(\mathrm{q} \\
23.3 ; \mathrm{q} 11.1) \mathrm{mat}\end{array}$ \\
\hline Duplicated segment & $11 \mathrm{q} 23.3-\mathrm{q} 24.2$ & 11q23-qter & $11 \mathrm{q} 23 \mathrm{q}$ ter & $11 \mathrm{q} 23.3 \mathrm{q} 24$ & 11923.3925 & dup(11)(q23q23) & $11 \mathrm{q} 23.3 \mathrm{q} 24.3$ & 11q23.1-qter & $\frac{11923.3925}{11925}$ \\
\hline $\begin{array}{l}\text { Familial/de novo } \\
\text { Tov }\end{array}$ & Familial & Familial & Familial & De novo & Familial & De novo & Familial & Familial & Familial \\
\hline $\begin{array}{l}\text { Intellectual disability } \\
\text { Hol }\end{array}$ & $+\frac{+}{-t}$ & $+\frac{+}{+\alpha}$ & $\frac{t}{+t+}$ & + & + & + & + & + & + \\
\hline $\begin{array}{l}\text { Hypotonia//ypertonicity } \\
\text { Seizures }\end{array}$ & $\frac{1}{-}$ & $\frac{1-}{-}$ & $\frac{++}{-}$ & $\frac{t+1}{t}$ & $+\frac{1}{-}$ & $\frac{-1+}{+\infty}$ & $+\frac{1+}{-1}$ & $\frac{-1+4}{+}$ & $\frac{+\%-}{-}$ \\
\hline $\begin{array}{l}\text { Seraines abnormality } \\
\text { Bran }\end{array}$ & - & + & - & $\frac{7}{-}$ & $\mathrm{N} / \mathrm{A}$ & 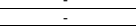 & + & $+\frac{7}{+}$ & + \\
\hline $\begin{array}{l}\text { Microcephaly } \\
\end{array}$ & + & + & + & + & - & N/A & + & + & + \\
\hline $\begin{array}{l}\text { Micrognathia } \\
\end{array}$ & + & + & + & $\mathrm{N} / \mathrm{A}$ & + & + & + & - & + \\
\hline $\begin{array}{l}\text { Triangular face } \\
\end{array}$ & - & - & - & + & - & + & + & - & - \\
\hline $\begin{array}{l}\text { Ocular defects } \\
\text { Shot noge }\end{array}$ & + & + & + & - & - & - & + & - & - \\
\hline$\frac{\frac{\text { Short nose }}{\text { Broad nose }}}{}$ & + & $\frac{+}{N / A}$ & + & Breached nose & + & - & + & + & + \\
\hline $\begin{array}{l}\text { Long philtrum } \\
\end{array}$ & - & - & + & & - & - & 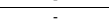 & + & + \\
\hline High arched palate & + & + & - & - & + & - & - & - & + \\
\hline Abnormal ears & 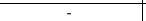 & + & + & + & + & + & + & - & - \\
\hline Congenital heart defect & - & + & + & & + & & + & + & - \\
\hline Inguinal hernia & - & & + & $\mathrm{N} / \mathrm{A}$ & & + & & + & - \\
\hline Speech delay & & & + & + & $\mathrm{N} / \mathrm{A}$ & & + & + & + \\
\hline Developmental delay & + & + & + & + & + & + & + & + & + \\
\hline
\end{tabular}

Microcephaly and micrognathia were also common clinical features among several patients with partial trisomy 11q23 syndrome (5/9), but short nose, high arched palate, and long philtrum were unique to the case we report here. Although abnormal ears and congenital heart defects were reported as common features (in 6/9 and 5/9 cases with partial trisomy 11q23 syndrome, respectively), these were not observed in our patient. In all cases, severity of the disability was highly variable, and the impact on patient development could not be evaluated in some patients due to early mortality (Maruyama et al., 2001; Klaassens et al., 2006).

In most cases, trisomy $11 \mathrm{q}$ is not restricted to $11 \mathrm{q}$, and involves genetic material from other chromosomes, often including a partial monosomy or trisomy of another chromosome derived from a parental translocation in addition to the distal region. (Yelavarthi and Zunich, 2004). Our patient's case involved the partial trisomy of chromosome 22q. Recently, a microduplication of 22q11.2 syndrome was identified and associated with DiGeorge/Velocardiofacial syndrome (DGS/VCFS). The 22q11.2 region is susceptible to chromosomal rearrangements (Brunet et al., 2006), and the clinical characteristics of partial microduplication of $22 \mathrm{q}$ syndrome have been described as extremely variable, ranging from mild learning disabilities to severe congenital malformations (Portnoï et al., 2005; Tarsitano 
et al., 2014). Typically, the phenotype of microduplication of 22q11.2 syndrome includes intellectual disability, heart defects, urogenital abnormalities, velopharyngeal insufficiency, down-slanting palpebral fissures, telecanthus, long narrow face, and nasal speech. Our patient exhibited a 22q11.2 microduplication region that is $3.46 \mathrm{Mb}$ in size, close to the classical reported region. Another case was reported in a 5-month-old infant with a maternally inherited microduplication of 22q11.2 spanning $2.5 \mathrm{Mb}$, but this individual had no particular phenotypic abnormalities, and psychomotor development was reported to be normal (Christopoulou et al., 2013). Thus, there seems to be no certain correlation between the size of duplication of $22 \mathrm{q} 11.2$ and the phenotype, suggesting that genetic and epigenetic modifying factors may play an important role in determining the disease phenotype and severity (Fernández et al., 2009).

Array CGH analysis of our patient revealed that the breakpoints on chromosome 11 were at q23.3-q25, and on chromosome 22 were at q11.1-q11.21. The gene content of the duplicated regions was further investigated using the following websites: http://omim. org/, http://decipher.sanger.ac.uk/, and http://genome.ucsc.edu/cgi-bin/hgGatewaywebsites. There are 128 genes in the duplicated region on 11q23.3-q25; mutations found in 40 of these genes are considered to be the molecular basis of other diseases as summarized below: $B A C E 1$, located at 11q23.3, has been reportedly involved in cerebral deposition of amyloid beta peptide, which is an early indicator of Alzheimer disease (Vassar et al., 1999). Gene knockout and overexpression experiments showed that BACE1 was related with nervous system development (Long et al., 2014). BSX, located at 11q24.1, is a DNA-binding protein and a transcriptional activator found to be essential for fetal growth and development (Chu and Ohtoshi, 2007). Alterations in $A O C H$, located at chromosome 11 were reported in a family with acromegaloid features, submucosal cleft palate, and diaphragmatic hernia (Stratakis et al., 2001). ZNF202 was related to lipid metabolism and cardiac function (Razzaghi et al., 2012). FEZ1 was related with axon growth (Bloom and Horvitz, 1997). The importance of these genes in other diseases suggests that abnormalities in these genes also contributes to the common features of the partial trisomy 11q syndrome, including intellectual disability, short stature, dysmorphic features, hypotonia, brain malformations, and congenital heart malformations (Ben-Abdallah-Bouhjar et al., 2013).

The $3.46 \mathrm{Mb}$ duplicated region of 22q11.1-22q11.21 was found to be located within a 22q11.21 microduplication syndrome region that contains 38 genes (OMIM \#608363). Increased copy numbers of this $22 \mathrm{q} 11.2$ segment may contribute to a specific set of phenotypes related to the development of learning and cognition. Diverse phenotypes associated with chromosome 22q11.2 microduplication syndrome have been described, and the most frequently reported features are mental retardation/learning difficulties, deficits in memory performance, perceptual organization, and verbal comprehension, attention deficit hyperactivity disorder, and speech impairment (97\%; Wentzel et al., 2008). Other characteristics include delayed psychomotor development (67\%), growth retardation (63\%), and muscular hypotonia (43\%; Wentzel et al., 2008). The most common dysmorphic features were hypertelorism (70\%), broad flat nose (53\%), micrognathia (52\%), velopharyngeal insufficiency $(48 \%)$, dysplastic ears (45\%), epicanthal folds (42\%), and down-slanting palpebral fissures $(41 \%$; Wentzel et al., 2008). The duplication of 22q11.1-22q11.21 involves the same region as that deleted in DGS (OMIM \#188400) and VCFS (OMIM \#192430). Duplication of chromosome 22q11.2 is associated with elevated rates of mental retardation, autism, and other behavioral phenotypes, and probably includes abnormalities in several key genes such as TXNRD2, COMT, ARVCF, 
and TBX1. TXNRD2 is a thioredoxin reductase that directly reduces proteins (Gasdaska et al., 1999); COMT is one of the most extensively studied 22q11.2 genes related to cognitive function (Rosa et al., 2004) and ARVCF may contribute to the phenotype of VCFS (Suzuki et al., 2009). Moreover, $T B X 1$ has been shown to be the major genetic component responsible for the features of DGS/VCFS. TBX1 gain-of-function mutations result in the same phenotype as haploinsufficiency caused by loss-of-function mutations or deletions (Zweier et al., 2007). As the features of 22q11.2 microduplication syndrome are variable, a few typical clinical characteristics have been hard to determine. Some reports even questioned whether the 22q11.2 microduplication syndrome is a real syndrome (Courtens et al., 2008). Therefore, it may be difficult to attribute specific clinical features presented by our patient to the 22q11.2 microduplication syndrome.

In conclusion, we described a rare case of an unbalanced karyotype including trisomy $11 \mathrm{q} 23.3-11 \mathrm{q} 25$ and trisomy $22 \mathrm{q} 11.1-22 \mathrm{q} 11.21$. We concluded that a patient presenting intellectual disability may possess a partial duplication of $11 \mathrm{q}$, especially if other specific features such as brain malformations, agenesis of corpus callosum, and speech delay are observed. Additionally, 22q11.21 duplication may be associated with a diverse range of congenital malformations and dysmorphic features. Identification of these karyotypic abnormalities can be technically challenging; in the case of our patient, molecular cytogenetic analysis was used to precisely delineate the abnormality. Molecular cytogenetic analysis and genetic diagnoses are becoming increasingly important in the clinic, and the exact characterization of any abnormal chromosomal features is critically important for genetic counseling. Our case demonstrates the importance of a clear cytogenetic diagnosis, not only for providing an explanation of our patient's dysmorphic features, but also in facilitating counseling for her parents regarding future pregnancies.

\section{ACKNOWLEDGMENTS}

We would like to thank all the patients and their families who participated in this study.

\section{REFERENCES}

Ben-Abdallah-Bouhjar I, Mougou-Zerelli S, Hannachi H, Ben-Khelifa H, et al. (2013). Phenotype and micro-array characterization of duplication 11q22.1-q25 and review of the literature. Gene 519: 135-141. http://dx.doi. org/10.1016/j.gene.2013.01.017

Bloom L and Horvitz HR (1997). The Caenorhabditis elegans gene unc-76 and its human homologs define a new gene family involved in axonal outgrowth and fasciculation. Proc. Natl. Acad. Sci. USA 94: 3414-3419. http://dx.doi. org/10.1073/pnas.94.7.3414

Brunet A, Gabau E, Perich RM, Valdesoiro L, et al. (2006). Microdeletion and microduplication 22q11.2 screening in 295 patients with clinical features of DiGeorge/Velocardiofacial syndrome. Am. J. Med. Genet. A. 140: 2426-2432.

Burnside RD, Lose EJ, Domínguez MG, Sánchez-Corona J, et al. (2009). Molecular cytogenetic characterization of two cases with constitutional distal 11q duplication/triplication. Am. J. Med. Genet. A. 149A: 1516-1522. http://dx.doi. org/10.1002/ajmg.a.32906

Christopoulou G, Sismani C, Sakellariou M, Saklamaki M, et al. (2013). Clinical and molecular description of the prenatal diagnosis of a fetus with a maternally inherited microduplication 22q11.2 of 2.5 Mb. Gene 527: 694-697. http:// dx.doi.org/10.1016/j.gene.2013.02.044

Chu HY and Ohtoshi A (2007). Cloning and functional analysis of hypothalamic homeobox gene Bsxla and its isoform, Bsx1b. Mol. Cell. Biol. 27: 3743-3749. http://dx.doi.org/10.1128/MCB.01561-06

Courtens W, Schramme I and Laridon A (2008). Microduplication 22q11.2: a benign polymorphism or a syndrome with 
a very large clinical variability and reduced penetrance?--Report of two families. Am. J. Med. Genet. A. 146A: 758763. http://dx.doi.org/10.1002/ajmg.a.31910

Delobel B, Delannoy V, Pini G, Zapella M, et al. (1998). Identification and molecular characterization of a small 11q23.3 de novo duplication in a patient with Rett syndrome manifestations. Am. J. Med. Genet. 80: 273-280. http://dx.doi. org/10.1002/(SICI) 1096-8628(19981116)80:3<273::AID-AJMG19>3.0.CO:2-6

Fernández L, Nevado J, Santos F, Heine-Suñer D, et al. (2009). A deletion and a duplication in distal 22q11.2 deletion syndrome region. Clinical implications and review. BMC Med. Genet. 10: 48. http://dx.doi.org/10.1186/1471-2350$\underline{10-48}$

Forsythe MG, Walker H, Weiss L, Roberson JR, et al. (1988). Duplication and deletion 11q23-q24 recombinants in two offspring of an intrachromosomal insertion ("shift") carrier. Henry Ford Hosp. Med. J. 36: 183-186.

Francke U, Weber F, Sparkes RS, Mattson PD, et al. (1977). Duplication 11 (q21 to 23 leads to qter) syndrome. Birth Defects Orig. Artic. Ser. 13 (3B): 167-186.

Gasdaska PY, Berggren MM, Berry MJ and Powis G (1999). Cloning, sequencing and functional expression of a novel human thioredoxin reductase. FEBS Lett. 442: 105-111. http://dx.doi.org/10.1016/S0014-5793(98)01638-X

Greig F, Rosenfeld W, Verma RS, Babu KA, et al. (1985). Duplication 11 (q22----qter) in an infant. A case report with review. Ann. Genet. 28: 185-188.

Klaassens M, Scott DA, van Dooren M, Hochstenbach R, et al. (2006). Congenital diaphragmatic hernia associated with duplication of 11q23-qter. Am. J. Med. Genet. A. 140: 1580-1586. http://dx.doi.org/10.1002/ajmg.a.31321

Long JM, Ray B and Lahiri DK (2014). MicroRNA-339-5p down-regulates protein expression of b-site amyloid precursor protein-cleaving enzyme 1 (BACE1) in human primary brain cultures and is reduced in brain tissue specimens of Alzheimer disease subjects. J. Biol. Chem. 289: 5184-5198. http://dx.doi.org/10.1074/jbc.M113.518241

Maruyama K, Koizumi T and Ikeda H (2001). Partial monosomy 10q with partial trisomy 11q due to paternal balanced translocation. J. Paediatr. Child Health 37: 198-200. http://dx.doi.org/10.1046/j.1440-1754.2001.00587.x

Partida-Pérez M, Domínguez MG, Sánchez-Corona J, Castañeda-Cisneros G, et al. (2006). Constitutional duplication $11 \mathrm{q} 23$ de novo involving the MLL gene. Genet. Couns. 17: 155-159.

Pfeiffer RA and Schütz C (1993). Tandem duplication 11q23-ter in the dysmorphic child of a retarded mother mosaic for the same anomaly with no apparent abnormalities. Ann. Genet. 36: 163-166.

Portnoï MF, Lebas F, Gruchy N, Ardalan A, et al. (2005). 22q11.2 duplication syndrome: two new familial cases with some overlapping features with DiGeorge/velocardiofacial syndromes. Am. J. Med. Genet. A. 137: 47-51. http:// dx.doi.org/10.1002/ajmg.a.30847

Razzaghi H, Santorico SA and Kamboh MI (2012). Population-based resequencing of LIPG and ZNF202 genes in subjects with extreme HDL levels. Front. Genet. 3: 89. http://dx.doi.org/10.3389/fgene.2012.00089

Rosa A, Peralta V, Cuesta MJ, Zarzuela A, et al. (2004). New evidence of association between COMT gene and prefrontal neurocognitive function in healthy individuals from sibling pairs discordant for psychosis. Am. J. Psychiatry 161: 1110-1112. http://dx.doi.org/10.1176/appi.ajp.161.6.1110

Smeets D, van Ravenswaaij C, de Pater J, Gerssen-Schoorl K, et al. (1997). At least nine cases of trisomy 11q23-->qter in one generation as a result of familial $\mathrm{t}(11 ; 13)$ translocation. J. Med. Genet. 34: 18-23. http://dx.doi.org/10.1136/ jmg.34.1.18

Stratakis CA, Turner ML, Lafferty A, Toro JR, et al. (2001). A syndrome of overgrowth and acromegaloidism with normal growth hormone secretion is associated with chromosome 11 pericentric inversion. J. Med. Genet. 38: 338-343. http://dx.doi.org/10.1136/jmg.38.5.338

Suzuki G, Harper KM, Hiramoto T, Funke B, et al. (2009). Over-expression of a human chromosome 22q11.2 segment including TXNRD2, COMT and ARVCF developmentally affects incentive learning and working memory in mice. Hum. Mol. Genet. 18: 3914-3925. http://dx.doi.org/10.1093/hmg/ddp334

Tarsitano M, Ceglia C, Novelli A, Capalbo A, et al. (2014). Microduplications in 22q11.2 and 8q22.1 associated with mild mental retardation and generalized overgrowth. Gene 536: 213-216. http://dx.doi.org/10.1016/j.gene.2013.11.051

Tuğ E, Yirmibeş Karaoğuz M, Kayhan G, Ergün MA, et al. (2014). Chromosomal-array analysis reveals partial 11q duplication and partial 12p deletion in a mildly affected case. Am. J. Med. Genet. A. 164A: 1770-1776. http://dx.doi. org/10.1002/ajmg.a.36495

Vassar R, Bennett BD, Babu-Khan S, Kahn S, et al. (1999). Beta-secretase cleavage of Alzheimer's amyloid precursor protein by the transmembrane aspartic protease BACE. Science 286: 735-741. http://dx.doi.org/10.1126/ science. 286.5440 .735

Wentzel C, Fernström M, Ohrner Y, Annerén G, et al. (2008). Clinical variability of the 22q11.2 duplication syndrome. Eur. J. Med. Genet. 51: 501-510. http://dx.doi.org/10.1016/j.ejmg.2008.07.005

Yelavarthi KK and Zunich J (2004). Familial interstitial duplication of 11q; partial trisomy (11)(q13.5q21). Am. J. Med. 
Genet. A. 126A: 423-426. http://dx.doi.org/10.1002/ajmg.a.20610

Zimberg-Bossira A, Smolkin T, Gildish A, Moustafa-Hawash N, et al. (2011). 'Pure' partial trisomy 11q(11q23.1®11qter): expanding the phenotype. Clin. Dysmorphol. 20: 225-228. http://dx.doi.org/10.1097/MCD.0b013e328349bcf8

Zweier C, Sticht H, Aydin-Yaylagül I, Campbell CE, et al. (2007). Human TBX1 missense mutations cause gain of function resulting in the same phenotype as 22q11.2 deletions. Am. J. Hum. Genet. 80: 510-517. http://dx.doi. org/10.1086/511993 